\title{
МОРФОМЕТРИЧНА ХАРАКТЕРИСТИКА МОРФОЛОГІЧНИХ ЗМІН СТРУКТУР СІМ'ЯНИКІВ В УМОВАХ ПОСТРЕЗЕКЦІЙНОЇ АРТЕРІАЛЬНОЇ ЛЕГЕНЕВОЇ ГІПЕРТЕНЗІЇ
}

\author{
ОМ. С. Гнатюк, С. О. Коноваленко, Л. В. Татарчук \\ Тернопільський національний медичний університет імені І. Я. Горбачевського МОЗ України
}

РЕзюМЕ. Легенева гіпертензія і легеневе серце призводять до венозного повнокрів'я та застою у органах великого кола кровообігу. Особливості ремоделювання структур сім'яників при цьому маловивчені.

Мета - морфометрично вивчити особливості морфологічних змін структур сім'яників в умовах пострезекційної легеневої гіпертензії.

Матеріал і методи. Морфологічно досліджені сім'яники 45 білих щурів, які були поділені на три групи. 1-а -15 контрольних тварин, 2-а - 22 щури з пострезекційною артеріальною легеневою гіпертензією і компенсованим легеневим серцем, 3-я - 8 тварин з пострезекційною артеріальною легеневою гіпертензією і декомпенсованим легеневим серцем. Евтаназію дослідних тварин здійснювали кровопусканням в умовах тіопенталового наркозу через місяць від початку досліду. Легеневу гіпертензію та легеневе серце моделювали шляхом виконання правосторонньої пульмонектомії. Проводили окреме зважування камер серця, їх планіметрію. 3 сім'яників виготовляли гістологічні мікропрепарати. Морфометрично на мікропрепаратах визначили діаметри сім'яних канальців, товщину їх стінки, кількість клітин епітеліо-сперматогенного шару, кількість клітин Сертолі, тубуло-інтерстиційний індекс, індекс Лейдіга, індекс інтенсивності сперматогенезу. Кількісні показники обробляли статистичними методами.

Результати. Світлооптично венозні судини розширені, переповнені кров'ю. Відмічався виражений перивазальний набряк, який місцями звужував і деформував судини та сім'яні канальні. Венозні судини гемомікроциркуляторного русла нерівномірно розширені, варикозно змінені, з сакуляціями, переповнені кров'ю, з явищами стазу, тромбозу, що посилювало гіпоксію, яка ускладнювалася дистрофією та некрозами ендотеліоцитів, міоцитів судин, клітин Лейдіга, Сертолі, сперматогенних епітеліоцитів, стромальних структур, інфільтративними та склеротичними процесами. Порушення сперматогенезу підтверджувалося атрофією сім'яних канальців (зменшення їх діаметра, кількості клітин епітеліо-сперматогенного шару, індексу інтенсивності сперматогенезу, потовщення стінки сім'яних канальців). Суттєво ремоделювалися інтерстиційний та ендокринний компоненти сім'яників, що підтверджувалося істотними змінами тубуло-інтерстиційного індексу та індексу Лейдіга. Зміни досліджуваних морфометричних параметрів домінували при декомпенсації легеневого серця, де гемодинамічні зміни були найвираженішими.

Висновок. Пострезекційна легенева гіпертензія та легеневе серце призводять до суттєвого ремоделювання структур сім'яників, яке характеризується вираженим венозним повнокров'ям, гіпоксією, атрофічними дистрофічними, некробітичними, інфільтративними та склеротичними процесами, суттєвими змінами ендокринного, сперматогенного та інтерстиційного компонентів з домінуванням їх при декомпенсації легеневого серця.

ключовІ СловА: пострезекційна легенева гіпертензія, сім'яники, морфометрія.

Вступ. Легенева гіпертензія, зумовлена захворюванням легень, нерідко трапляється в клінічній практиці та ускладнюється переважно гіперфункцією та гіпертрофією правого шлуночка, тобто розвитком легеневого серця [3, 8, 9]. Сьогодні дослідники вказують, що хронічне легеневе серце характеризується гіпертрофією, дилатацією і дисфункцією м'яза правого шлуночка, що викликано ураженням легеневої паренхіми і/або легеневого судинного русла між місцем відходження стовбура легеневої артерії і місцем впадання легеневих вен у ліве передсердя. На сьогодні легеневе серце набуває все більшого значення у зв'язку із значним зростанням кількості хронічних обструктивних захворювань легень, хронічних форм туберкульозу, професійних ушкоджень легень, при яких основною причиною втрати працездатності та летальності є декомпенсація легеневого серця. Патогенез останньої складний і досить багатогранний, що значною мірою ускладнює адекватну й своєчасну діагностику легеневої гіпертензії та легеневого серця [3, 8, 9]. Гіпертензія у системі легеневої артерії і легеневе серце можуть також розвиватися після видалення значної частини легеневої паренхіми [3]. Варто вказати, що до сьогоднішнього дня дискусійними залишаються питання про поширеність гіпертрофії правого шлуночка при хронічних обструктивних захворюваннях легень, а також про роль легеневої гіпертензії в патогенезі легеневого серця [3, 9], а зміни судинного русла інших органів при цій патології досліджені недостатньо [5]. В останні роки морфологи все ширше використовують морфометричні методи дослідження, які дозволяють кількісно та найбільш об'єктивно оцінити різні фізіологічні та патологічні процеси і логічно інтерпретувати їх $[1,3]$.

Мета - морфометрично вивчити особливості морфологічних змін структур сім'яників в умовах 
Огляди літератури, оригінальні дослідження, погляд на проблему, випадок з практики, короткі повідомлення пострезекційної артеріальної легеневої гіпертензії.

Матеріал і методи дослідження. Комплексом морфологічних методів досліджені сім'яники 45 статевозрілих білих щурів-самців, які були поділені на три групи. 1-а група (контрольна) включала 15 тварин, які перебували у звичайних умовах віварію, 2-а - 22 щури з пострезекційною артеріальною легеневою гіпертензією і компенсованим легеневим серцем, 3-я - 8 тварин з пострезекційною артеріальною легеневою гіпертензією і декомпенсованим легеневим серцем. Останнє підтверджувалося задишкою, синюшністю слизових оболонок, гідротораксом, гідроперикардом, застійними явищами в органах великого кола кровообігу. Евтаназію дослідних тварин здійснювали кровопусканням в умовах тіопенталового наркозу через місяць від початку експерименту. Пострезекційну артеріальну легеневу гіпертензію та легеневе серце моделювали шляхом виконання правосторонньої пульмонектомії [3]. Серце розрізали за методикою Г. Г. Автанділова, проводили окреме зважування камер серця, їх планіметрію [1]. 3 сім'яників вирізали шматочки, які фіксували в 10 \% розчині формаліну, проводили через етилові спирти зростаючої концентрації та поміщали у парафін. Мікротомні зрізи після депарафінізації забарвлювали гематоксиліном-еозином, за методом ван-Гізон, Маллорі, Гейденгайна, Вейгерта, толуїдиновим синім [4]. Морфометрично на мікропрепаратах сім'яників визначили діаметри сім'яних канальців (ДСК), товщину їх стінки (ТС), кількість клітин епіте-

ліо-сперматогенного шару (KEC) у канальці, кількість клітин Сертолі (КС) на каналець, визначали тубуло-інтерстиційний індекс (ТІ - співвідношення площі сім'яних канальців до інтерстиційної тканини), індекс Лейдіга (ІЛ) - відносне число клітин Лейдіга, що оточують сім'яний каналець, індекс інтенсивності сперматогенезу (IC) - співвідношення клітин епітеліо-сперматогенного шару до клітин Лейдіга [2]. Кількісні показники обробляли статистично. Обробка отриманих результатів виконана у відділі системних статистичних досліджень Тернопільського національного медичного університету імені І. Я. Горбачевського МОЗ України в програмному пакеті Statistica. Різницю між порівнювальними величинами визначали за критеріями Стьюдента та Манна-Уїтні $[1,6]$. Проведення експериментів та евтаназію дослідних тварин проводили $з$ дотриманням «Загальних етичних принципів експериментів на тваринах", ухвалених Першим національним конгресом з біоетики (Київ, 2001), відповідно до «Європейської конвенції про захист хребетних тварин, що використовуються у дослідних та інших наукових цілях", а також Закону України «Про захист тварин від жорстокого поводження» (від 21.02.2006) [7].

Результати й обговорення. Планіметрією та окремим зважуванням камер серця встановлено, що правостороння пульмонектомія призводила до їх гіпертрофії та розширення з домінуванням маси правого шлуночка та його дилатації, тобто легеневого серця [3]. Результати проведеного морфометричного дослідження представлені в таблиці 1.

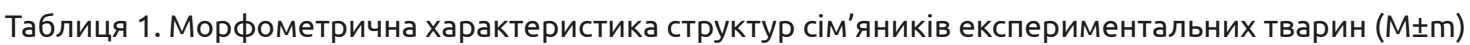

\begin{tabular}{|l|c|c|c|}
\hline \multirow{2}{*}{\multicolumn{1}{c|}{ Показник }} & \multicolumn{2}{c|}{ Група тварин } \\
\cline { 2 - 4 } & 1 -а & 2 -а & 3-я \\
\hline ДСК, МКм & $315,6 \pm 2,7$ & $269,5 \pm 2,4^{* * *}$ & $11,60 \pm 0,08^{* * *}$ \\
\hline TC, МКм & $9,30 \pm 0,06$ & $10,20 \pm 0,06^{* * *}$ & $67,1 \pm 0,7^{* * *}$ \\
\hline KEC & $97,2 \pm 0,9$ & $83,8 \pm 0,9^{* * *}$ & $5,80 \pm 0,05^{*}$ \\
\hline KC & $6,20 \pm 0,05$ & $6,08 \pm 0,06$ & $0,420 \pm 0,006^{* * *}$ \\
\hline TI & $0,560 \pm 0,004$ & $0,490 \pm 0,008^{* *}$ & $12,90 \pm 0,09^{* * *}$ \\
\hline IЛ & $8,30 \pm 0,07$ & $10,40 \pm 0,08^{* * *}$ & $7,20 \pm 0,06^{* * *}$ \\
\hline IC & $11,60 \pm 0,09$ & $11,20 \pm 0,12^{*}$ & \\
\hline
\end{tabular}

Примітка. *- ${ }^{*}<0,05 ;{ }^{* *}-p<0,01 ; * * *-p<0,001$, порівняно 3 1-ю групою.

Усестороннім аналізом даних вказаної таблиці встановлено, що досліджувані морфометричні параметри у 2-й та 3-й групах спостережень виявилися зміненими, порівняно з контролем. Так, діаметр сім'яних канальців в умовах компенсованого легеневого серця статистично достовірно ( $p<0,001)$ зменшився на 14,6 \%, а при його декомпенсації - на 33,3 \%, порівняно з контрольними величинами.
Товщина стінки сім'яних канальців у досліджуваних експериментальних умовах зростала. У 2-й групі спостережень вказаний морфометричний параметр з вираженою статистично достовірною різницею ( $<<0,001)$ виявився збільшеним на 9,7 \%, а у 3-й - на 24,7 \%. Кількість клітин епітеліосперматогенного шару в канальні у тварин 2-ї групи зменшилася з $(97,2 \pm 0,9)$ до $(83,8 \pm 0,9)$, тобто на $13,8 \%(p<0,001)$, а у $3-и ̆$ - на $30,9 \%(p<0,001)$. 
Огляди літератури, оригінальні дослідження, погляд на проблему, випадок з практики, короткі повідомлення

Змінилася також у даних умовах експерименту кількість клітин Сертолі. У 2-й групі спостережень досліджуваний морфометричний параметр дорівнював $(6,08 \pm 0,06)$. Цей морфометричний параметр був меншим за аналогічний контрольний показник $(6,20 \pm 0,06)$ на 1,9 \% (p>0,05). При декомпенсованому легеневому серці кількість клітин Сертолі статистично достовірно $(p<0,05)$ знизилася на 6,4%. Тубуло-інтерстиціальний індекс у експериментальних групах тварин статистично достовірно $(p<0,01)$ зменшився відповідно на $12,5 \%$ та $25,0 \%$, що свідчить про збільшення у тканинах сім'яників сполучнотканинних структур.

Індекс Лейдіга при компенсованому та декомпенсованому легеневому серці збільшувався. При цьому в 2-й групі спостережень цей морфометричний параметр з вираженою статистично достовірною різницею ( $p<0,001)$ зріс на $25,3 \%$, а у 3-й - на 55,4 \%. Індекс інтенсивності сперматогенезу у змодельованих експериментальних умовах суттєво зменшувався. Так, при компенсованому легеневому серці вказаний морфометричний параметр знизився на 3,5 \% $(p<0,05)$, а при його декомпенсації - на 37,9\% ( $p<0,001)$.

Світлооптично виявлено, що венозні судини розширені, переповнені кров'ю. Відмічався виражений перивазальний набряк, який місцями звужував і деформував судини та сім'яні канальні. Переважна більшість венозних судин гемомікроциркуляторного русла нерівномірно розширені, варикозно змінені, з частими сакуляціями, переповнені форменими елементами крові, з явищами стазу, тромбозу, що свідчить про виражене порушення їх дренажної функції [5]. Венозний застій у досліджуваних судинах призводив до посилення гіпоксії, дистрофії та некрозів ендотеліоцитів, міоцитів судин, клітин Лейдіга, Сертолі, сперма-

\section{ЛІТЕРАТУРА}

1. Автандилов Г. Г. Основы количественной патологии / Г. Г. Автандилов. - М. : Медицина, 2002. - 240 с.

2. Базалицькая С. В. Диагностические методы и критерии оценки биопсийного материала при мужском бесплодии / С. В. Базалицька, И. И. Горпиненко, А. М. Романенко // Здоровье мужчины. - 2004. - № 3. - С. 216-221.

3. Гнатюк М. С. Морфометрична оцінка структурної перебудови судин гемомікроциркуляторного русла шлуночків легеневого серця / М. С. Гнатюк, О. Б. Слабий, Л. В. Татарчук // Науковий вісник Ужгородського університету, Серія «Медицина». - 2015. - випуск 1 (51). C. $10-12$.

4. Горальський Л. П. Основи гістологічної техніки і морфофункціональні методи досліджень у нормі та при патології / Л. П. Горальський, В. Т. Хомич, О. І. Кононський. - Житомир : Полісся, 2011. - 288 с. тогенних епітеліоцитів, стромальних структур, інфільтративних та склеротичних процесів [3, 5]. Наведені морфологічні зміни у сім'яниках домінували при декомпенсації легеневого серця.

Досліджувані морфометричні параметри дали можливість оцінити в умовах змодельованої патології ступінь та особливості порушень сперматогенезу. Зміни останнього підтверджувалися атрофією сім'яних канальців (зменшення їх діаметра, кількості клітин епітеліо-сперматогенного шару, індексу інтенсивності сперматогенезу, потовщення стінки сім'яних канальців). Вираженого ремоделювання при цьому зазнавали також інтерстиційний та ендокринний компоненти досліджуваного органа, що підтверджувалося істотними змінами тубуло-інтерстиційного індексу та індексу Лейдіга. Варто зазначити, що ступінь змін досліджуваних морфометричних параметрів виявився найбільшим при декомпенсації легеневого серця, де гемодинамічні зміни були найвираженішими $[8,9]$.

Висновок. Пострезекційна артеріальна легенева гіпертензія та легеневе серце призводять до суттєвого ремоделювання структур сім'яників, яке характеризується вираженим венозним повнокров'ям, гіпоксією, атрофічними дистрофічними, некробітичними, інфільтративними та склеротичними процесами, суттєвими змінами ендокринного, сперматогенного та інтерстиційного компонентів з домінуванням їх при декомпенсації легеневого серця.

Перспективи подальших досліджень полягають у всебічному, адекватному дослідженні особливостей ремоделювання структур сім'яників при гемодинамічних порушеннях, що сприятиме покращенню діагностики, корекції та профілактики ускладнень при вказаних патологічних станах.

5. Грицуляк Б. В. Орхоепідидиміт / Б. В. Грицуляк, А. М. Спаська, В. Б. Грицуляк. - Івано-Франківськ : Прикарпатський національний університет, 2010. - 188 с.

6. Лапач С. Н. Статистические методы в медикобиологических исследованиях Excell / С. Н. Лапач, А. В. Губенко, П. Н. Бабич. - К. : Морион, 2001. - 410 с.

7. Резніков О. Г. Загальні етичні принципи експериментів на тваринах / О. Г. Резніков // Ендокринологія. 2003. - T. 8, № 1. - С. 142-145.

8. Семен Х. О. Особливості діагностики легеневої артеріальної гіпертензії / Х. О. Семен // Медицина транспорту України. - 2015. - № 2. - С. 72-80.

9. Galie N. Updated treatment algorithm of pulmonary arterial hypertension / N. Galie, P. Corris, A. Frost // J. Am. Coll. Cardiol. - 2013. - Vol. 62. - P. 60-72. 
Огляди літератури, оригінальні дослідження, погляд на проблему, випадок з практики, короткі повідомлення REFERENCES

1. Avtandilov, G.G. (2002). Osnovy kolichestviennoy patologicheskoy anatomii [Basis of quantitative pathological anatomy]. Moscow: Meditsyna [in Russian].

2. Bazalytskaya, S.V. (2004). Diagnostycheskye metody i kriterii otsenki biopsiynogo materiala pri muzhskom besplodii [Diagnostic methods and criteria for evaluation of biopsy material in male infertility]. Zdorovye muzhchiny-Men's Health, 3, 216-221 [in Ukrainian].

3. Hnatiuk, M.S., Tatarchuk, L.V., \& Slabyi, O.B. (2015). Morfometrychna otsinka strukturnoi perebudovy sudyn hemomikrotsyrkuliatornoho rusla shlunochkiv lehenevoho sertsia [Morphometric evaluation of the structural reconstruction of the vessels of the hemomicrocirculatory bed of the ventricles of the cor pulmonale]. Naukovyi visnyk Uzhhorodskoho universytetu, Seriia "Medytsyna" - Scientific Bulletin of the Uzhhorod University. Series "Medicine", 1 (51), 10-12 [in Ukrainian].

4. Horalskyi, L.P., Khomych, V.P., \& Konopskyi, O.I. (2011). Osnovy histolohichnoi tekhniky i morfofunktsionalni metody doslidzhennia u normi ta pry patolohii [Fundamentals of histological technique and morphofunctional methods of research in normal and pathology]. Zhytomyr: Polissia [in Ukrainian].

5. Hrytsuliak, B.V., Spaska, A.M., \& Hrytsuliak, V.B. (2010). Orkhoepidydymit [Orhoepididymitis]. Ivano-Frankivsk: Precarpathian National University [in Ukrainian].

6. Lapach S.N., Gubenko A.V., \& Babich P.N. (2001). Statisticheskiye metody $v$ mediko-biologicheskikh issledovaniyakh Excell [Statistical Methods in Excel Biomedical Research]. Kyiv: Morion [in Ukrainian].

7. Reznikov, O.H. (2003). Zahalni etychni pryntsypy eksperymentiv na tvarynakh [General ethical principles of animal experiments]. Endokrynolohiia-Endocrynology, 8, 1, 142-145 [in Ukrainian].

8. Semen, Kh.O. (2015). Osoblyvosti diahnostyky lehenevoi arterialnoi hipertenzii [Features of diagnostics of pulmonary arterial hypertension]. Medytsyna transportu Ukrainy - Medicine of Transport of Ukraine, 2, 72-80 [in Ukrainian].

9. Galie, N., Corris, P., Frost, A. (2013). Updated treatment algorithm of pulmonary arterial hypertension. J. Am. Coll. Cardiol., 62, 60-72.

\title{
МОРФОМЕТРИЧЕСКАЯ ХАРАКТЕРИСТИКА МОРФОЛОГИЧЕСКИХ ИЗМЕНЕНИЙ СТРУКТУР СЕМЕННИКОВ В УСЛОВИЯХ ПОСТРЕЗЕКЦИОННОЙ АРТЕРИАЛЬНОЙ ЛЕГОЧНОЙ ГИПЕРТЕНЗИИ
}

\author{
ФМ. С. Гнатюк, С. А. Коноваленко, Л. В. Татарчук
}

Тернопольский национальный медицинский университет имени И. Я. Горбачевского моз Украины

РЕЗЮМЕ. Легочная гипертензия и легочное сердце приводят к венозному полнокровию и застою у органах большого круга кровообращения. Особенности ремоделирования структур семяников при этом малоизучены.

Цель - морфометрически изучить особенности морфологических изменений структур семенников в условиях пострезекционной легочной гипертензии.

Материал и методы. Морфологически исследованы семенники 45 белых крыс, которые были поделены на три группы. Первая группа включала 15 контрольных животных, 2 - 22 крысы с пострезекционной артериальной легочной гипертензией и компенсированным легочным сердцем, 3 - 8 животных с пострезекционной артериальной легочной гипертензией и декомпенсированным легочным сердцем. Эвтаназию животных осуществляли кровопусканием в условиях тиопенталового наркоза через месяц от начала эксперимента. Пострезекционную артериальную легочную гипертензию и легочное сердце моделировали путем выполнения правосторонней пульмонэктомии. Проводили отдельное взвешивания камер сердца, их планиметрию. Из семенников изготавливали гистологические микропрепараты. Морфометрически на микропрепаратах определяли диаметры семенных канальцев, толщину их стенки, количество клеток эпителио-сперматогенного слоя, клеток Сертоли, тубуло-интерстициальный индекс, индекс Лейдига, индекс интенсивности сперматогенеза. Количественные показатели обрабатывали статистически.

Результаты. Светооптически венозные сосуды расширены, переполнены кровью. Отмечался выраженный перивазальний отек, который местами суживал и деформировал сосуды и семенные канальцы. Венозные сосуды гемомикроциркуляторного русла неравномерно расширены, варикозно изменены, с частыми саккуляциями, переполнены форменными элементами крови, с явлениями стаза, тромбоза, что усиливало гипоксию, которая осложнялась дистрофией и некрозом эндотелиоцитов, миоцитов сосудов, клеток Лейдига, Сертоли, сперматогенных эпителиоцитов, стромальных структур, инфильтративными и склеротическими процессами. Нарушения сперматогенеза подтверждались атрофией семенных канальцев (уменьшение их диаметра, количества клеток эпителио-сперматогенного слоя, индекса интенсивности сперматогенеза, утолщение стенки семенных канальцев). Ремоделирование интерстициального и эндокринного компонентов исследуемого органа подтверждалось существенными изменениями тубуло-интерстициального индекса и индекса Лейдига. Изменения исследуемых морфометрических параметров доминировали при декомпенсации легочного сердца, при которой гемодинамические изменения были наиболее выражены.

Вывод. Пострезекционная артериальная легочная гипертензия и легочное сердце приводят к существенному ремоделированию структур семенников, характеризующемуся выраженным венозным полнокровием, 
Огляди літератури, оригінальні дослідження, погляд на проблему, випадок з практики, короткі повідомлення гипоксией, атрофическими, дистрофическими, некробиотическими, инфильтративными и склеротическими процессами, существенными изменениями эндокринного, сперматогенного и интерстициального компонентов с их доминированием при декомпенсации легочного сердца.

КЛЮчЕВЫЕ СЛОВА: пострезекционная легочная гипертензия; семяники; морфометрия.

\title{
MORPHOMETRIC CHARACTERISTIC OF MORPHOLOGICAL CHANGES IN THE STRUCTURES OF THE TESTES IN THE CONDITIONS OF POSTRESECTION ARTERIAL PULMONARY HYPERTENSION
}

\author{
@M. S. Hnatjuk, S. O. Konovalenko, L. V. Tatarchuk \\ I. Horbachevsky Ternopil National Medical University
}

SUMMARY. Pulmonary hypertension and cor pulmonale lead to venous plethora and stagnation in the organs of the large circulatory system. The peculiarities of the remodeling of the testes structures are poorly understood.

The aim - to study morphometrically the peculiarities of morphological changes of the structures of the testes in the conditions of postresection pulmonary hypertension.

Material and Methods. The morphologically examined testes of 45 white rats were divided into three groups. Group 1 - 15 control animals, group 2 - 22 rats with postresection arterial pulmonary hypertension and compensated cor pulmonale, group $3-8$ animals with postresection arterial pulmonary hypertension and decompensated cor pulmonale. Euthanasia of experimental animals was performed by bloodletting under thiopental anesthesia a month after the start of the experiment. Pulmonary hypertension and cor pulmonale were modeled by right pulmonectomy; conducted a separate weighing of the chambers of the heart, their planimetry. Histological micronutrients were made from the testes. Morphometrically on micropreparations determined the diameter of the tubules, the thickness of their walls, the number of cells of the epithelio-spermatogenic were determined layer, the number of Sertoli cells, the tubulo-interstitial index, the Leydig index, the intensity index of spermatogenesis. Quantitative indicators were processed statistically.

Results. Optically venous vessels dilated, filled with blood. There was marked perivasal edema, which in some places narrowed and distorted vessels and seminal tubules. Venous vessels of the hemomicrocirculatory bed unevenly expanded, varicosally altered, with sacculations, overflowing with stasis, thrombosis, aggravated hypoxia, complicated by dystrophy and necrosis of endothelial cells, myocytes of vessels, cells of Leydig, Sertoli, spermatogenic epitheliocytes, stromal structures, infiltrative and sclerotic processes. Violation of spermatogenesis was confirmed by atrophy of the seminal tubules (reduction of their diameter, number of cells of the epithelio-spermatogenic layer, index of spermatogenesis intensity, thickening of the wall of the seminal tubules). The interstitial and endocrine components of the testes were significantly remodeled, which was confirmed by significant changes in the tubulo-interstitial index and the Leydig index. Changes in the studied morphometric parameters were dominated at decompensation of the cor pulmonale, where hemodynamic changes were most pronounced.

Conclusion. Postresection pulmonary hypertension and cor pulmonale lead to significant remodeling of the structures of the testes, which is characterized by pronounced venous plethora, hypoxia, atrophic, dystrophic, necrobiotic, infiltrative and sclerotic processes, significant changes of endocrine, spermatogenic and interstitial components with their dominance at decompensation of cor pulmonale.

KEY WORDS: postresection pulmonary hypertension; testes; morphometry. 